DOI: http://dx.doi.org/10.33846/hn31003

http://heanoti.com/index.php/hn

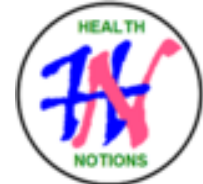

RESEARCH ARTICLE

URL of this article: http://heanoti.com/index.php/hn/article/view/hn31003

\title{
Relationship between Nutrition Deficiency, Oral Cavity Hygiene, and Oral Candidiasis in a 10-Years-Old Child
}

\author{
Sri Hernawati ${ }^{1(\mathrm{CA})}$ \\ Departement of Oral Medicine, Dentistry Faculty, Jember University, Indonesia; srihernawati.drg5@yahoo.com \\ (Corresponding Author)
}

\begin{abstract}
Candida albicans (C.albicans) is the main causative agent in oral candidiasis. Candida spp is a commensal microorganism or normal flora in the mouth without causing symptoms. Candida spp can be a pathogen when the body's condition decreases, systemic medical therapy for a long time, nutritional deficiencies and poor oral hygiene. This study aimed to determine the predisposing factors for the causes of oral candidiasis in 10-year-old pediatric patients who came to the Department of Oral Medicine, Dental Hospital of Dentistry Faculty of Jember University. The results of this study indicate a relationship between nutritional deficiencies and poor oral hygiene with oral candidiasis in children. White pseudomembranous plaque lesions are mostly found in the dorsal area of the tongue. Therapy for the patients is by applying nystatin anti-fungal, multivitamins, and education to improve nutrition and oral hygiene.
\end{abstract}

Keywords: nutritional deficiency; the oral cavity hygiene; oral candidiasis

\section{INTRODUCTION}

Oral candidiasis is a disease of the oral mucosa caused by Candida albicans, which is the most common fungus that infects the human body. ${ }^{(1),(2)}$ Candida albicans is a normal commensal fungus commonly found in the oral mucosa in healthy individuals. ${ }^{(2)}$ These fungi reach $40-60 \%$ from the population of microorganisms in the oral cavity. ${ }^{(19)}$ Nevertheless candida albicans can be a pathogen under certain conditions and can cause an infection called oral candidiasis. Candida albicans is the primary causative agent in oral candidiasis. They mainly settle in the posterior dorsum of the tongue. Oral candidiasis factors include nutritional deficiencies, malignant endocrine disorders, hematological disorders, immune disorders, xerostomia, medicines (corticosteroids, or long-term broad-spectrum antibiotics), dentures and smoking. ${ }^{(4)}$

Children aged 6-12 years shows a very rapid growth phase, thus the fulfillment of relatively large amounts of nutrition is needed. This age is also a period that is vulnerable to health problems, especially oral health problems. Nutritional condition is one of the factors that influence the growth and development of children. A person's nutritional condition is influenced by the food he eats. Several studies have shown that adequate food i.e. those that fulfill health and nutritional requirements in sufficient quantities and quality, affects children's productivity. Nutritional deficiencies such as iron deficiency, folic acid and vitamin B (B2, B6, and B12) can be associated with oral candidiasis. This shows that a poor diet can cause oral candidiasis. Although the relationship between nutritional deficiencies and oral candidiasis is not further explained in medical science, there are clear indications that the two are related. ${ }^{(5)}$

Local factors that can affect oral candidiasis include oral hygiene and saliva quality. Low oral hygiene has more number of candida albicans colonies than that of subjects with good oral hygiene. ${ }^{(6)}$ Handling of oral candidiasis should lead to identification of the factors underlying the cause of the disease through clinical examination and history of patient's disease. ${ }^{(7)}$ 


\section{METHODS}

A 10-year-old girl came to the Dental Hospital, Jember University complaining about her tongue that felt thick and white since \pm 3 weeks ago. She told that she felt uncomfortable when eating and had bad breath leading to less confidence when talking. The patient had never checked the condition. She did not have a history of systemic disease, and the current condition does not hurt.

\section{RESULTS}
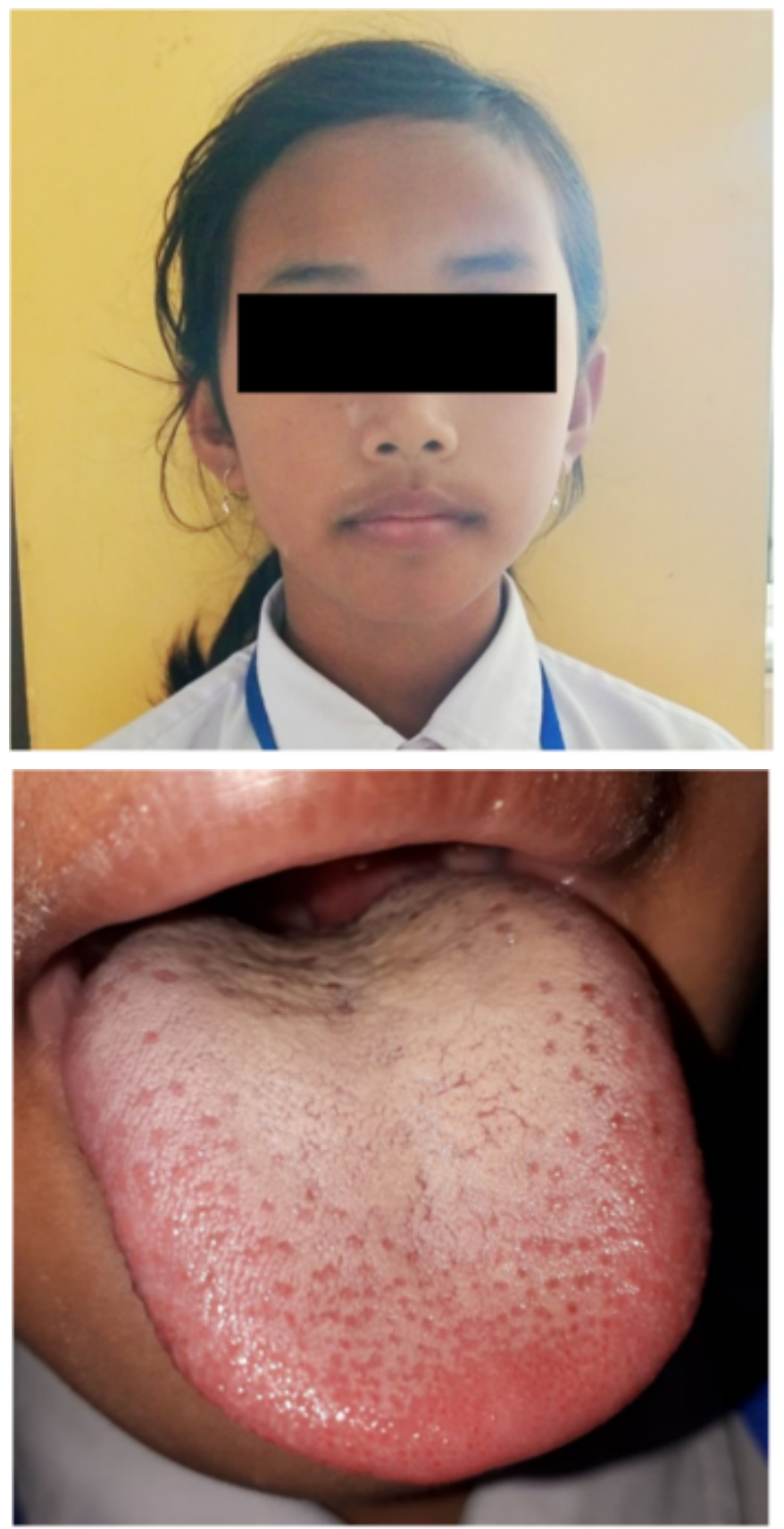

Figure 1. Extra oral and intra oral pictures of the patient with oral candidiasis 
The general condition of the patient was BW of $25 \mathrm{~kg}$, and BH of $120 \mathrm{~cm}$, BMI 17.36 (underweight). She was not in any treatment and had not taken certain drugs and hospitalizations in the past 6 months.

Extraoral clinical examination showed no abnormalities. Intraoral examination found an OHIS score of 2.16 and included in the medium category. The right and left cheek mucosa of posterior parts of the patient had macules with a diameter of $+2 \mathrm{~mm}$ cannot be scraped and did not feel hurt. The patient's central tongue to posterior appeared white plaque with irregular edges, clear border, can be scraped and did not feel hurt. Investigation using oral swab obtained results of hyphae +3 (positive three) and spores +3 (positive three).

\section{DISCUSSION}

Candidiasis is a fungal infection that occurs because of excessive fungal growth, where under normal conditions, the fungus appears in equal amounts with other microorganisms (normal flora of the oral cavity). ${ }^{(8)}$ Several sufferers of oral candidiasis complaint about having pain or burning sensation. This condition can be caused by Candida attached to the mucous surface of the oral cavity or tongue through its hyphae, releasable, and leave red mucosa and sometimes accompanied by mild bleeding. This can cause pain and burning sensation in the oral cavity as a sign of inflammation. ${ }^{(4)}$

The factors triggering the occurrence of oral candidiasis lesions are thought to be caused by systemic factors, local factors, or a combination of systemic and local factors. The local factor meant is the presence of other oral lesions and oral hygiene. ${ }^{(4)}$ Poor oral hygiene, malnutrition, very young age, and consumption of formula milk using bottles are some of the predisposing factors for candidiasis. ${ }^{(2)}$

In this case, the patient was a 10-year-old girl, which was a very young age, with poor oral hygiene, many remaining teeth, and the remaining roots. Her body was smaller compared to children in her age ( $\mathrm{BW} \pm 26$ $\mathrm{kg}$ ). Weak general condition, clinically describes the occurrence of malnutrition. ${ }^{(2)}$

Research conducted by Hajjar et al. (2004) showed that a decrease in the concentration of total salivary protein could be caused by either malnutrition. ${ }^{(12)}$ The most common condition of malnutrition is lack of iron, the most commonly reduced essential micronutrient, which is involved in candida colonization. Iron deficiency reduces fungistatic action from transferrin and other iron-dependent enzymes. ${ }^{(11)}$

Subsequent research also states that good nutritional status helps saliva in preventing the growth of candida albican colonies by inhibiting the growth of yeast (spores). Saliva has a lot of protein as an anti-candida capacity, and malnutrition makes its secretions lower or decreases the activity of these proteins. However, the presence of malnutrition has more influence on the effectiveness of saliva against candida albicans compared to salivary protein concentrations. Poor oral hygiene can accelerate the growth of candida albicans. ${ }^{(13)}$

In the dorsum of the tongue there was white plaque, irregular edges, clear borders, could be scraped and did not hurt. Most oral lesions are in the form of white pseudomembranous plaque found on the dorsum of the tongue caused by colonization of Candida spp in the oral cavity that attaches to keratin, accumulation of food waste and keratin cells that experience necrosis. Lesions are mostly found in the dorsum of the tongue because the surface of the tongue is often in direct contact with food and its uneven surface is a retentive area against a collection of bacteria and food waste. ${ }^{(4)}$

Laboratory diagnoses can be conducted through examination of microscopic specimens. ${ }^{(8)}$ Candida albicans has the ability to experience reversible morphological changes between budding, pseudohyphae, and hyphae. All forms can appear on tissue specimens. Yeast cells can spread effectively, while hyphae are thought to have the potential to invade the epithelium and endothelial tissue and help prevent ingestion of macrophages. ${ }^{(9)}$

Candida albicans attaches to epithelial cells due to interactions between candida surface glycoproteins and epithelial cells. Furthermore, candida secretes keratinolytic substances (phospholipase), which hydrolyze epithelial cell membrane phospholipids. The form of pseudohyphae candida also facilitates fungal invasion of the tissue, then in the candida tissue secretes the neutrophil chemotatic factor which will cause an acute inflammatory reaction. The outer layer of candida which contains manno protein is antigenic thus it activates complement and stimulates the formation of immunoglobulin. The role of antibodies as a host's defense mechanism is unclear. Immunoglobulin will form an antigen-antibody complex on the surface of the candida cell, which can protect candida from host immunity. Candida albicans also secretes toxic substances against other neutrophils and phagocytes. ${ }^{(9)}$

Therapy for this case uses topical antifungal therapy (nystatin) and multivitamin administration and application of a tongue cleaner for mechanical cleansing. Therapy with topical antifungals has several advantages over systemic therapy i.e. side effects and lower medicine interactions, localized therapy, and lower costs. $^{(9)}$ There are no medicine interactions and significant side effects on the use of nystatin as anticandidiasis. $^{(10)}$

Topical antifungal groups commonly used in candidiasis include: imidazole and polyene. Polyene is the first agent found as an antifungal. Nystatin and amphotericin B are the two main topical antifungal polyene 
medicines. Nystatin binds irreversibly to membrane sterols found in Candida species. Polyene molecules exhibit high affinity for sterol fungi, including ergosterol, rather than human sterols. This irreversible bond makes a hole in the membrane, causing a leak from the intracellular component that eradicates fungi cells. ${ }^{(9)}$

Nystatin is fungistatic at low concentrations, but at high concentrations it can be fungicidal. Nystatin is not soluble in water and is not absorbed from the intact skin, digestive tract, or vagina. Nystatin works as a topical agent because it is not absorbed in the digestion. Topical nystatin is used to treat mucocutaneous candidiasis caused by candida albicans and other susceptible species e.g. candida parapsilosis, candida tropicalis, and candida krusei. ${ }^{(9)}$

Treatment of oropharyngeal candidiasis, oral nystatin suspension of 100,000 U / ml or oral amphotericin B suspension $1000 \mathrm{mg} / \mathrm{ml}, 4$ times a day, held in the mouth for 5 minutes then swallowed. Clinical healing of nystatin therapy is reported to be $29-85 \%$. Most lesions will disappear within 2 weeks. Failure can occur because the suspension is swallowed too quickly thus plaque contact with the medicine becomes minimal and reduces efficacy.

Nystatin can be administered as a topical medicine for the treatment of candidiasis, administered by gargling 2 to $4 \mathrm{ml}$ for 2 minutes, after which the patient is forbidden to eat and drink for 20 minutes. Therapy can be administered for 7-14 days and continued for 2-3 days after the clinical signs of candidiasis are lost, and maintenance of oral hygiene. If there is a systemic condition, topical administration is sometimes not very effective that systemic administration is necessary. ${ }^{(4)}$

\section{CONCLUSION}

Candidiasis/yeast infection is a fungal infection that occurs due to excessive fungal growth, where in normal condition, the fungus appears in small amounts (normal flora of the oral cavity). Poor oral hygiene, malnutrition and very young age are some of the predisposing factors for oral candidiasis. Therapy for this case uses topical anti-fungal therapy and multivitamin administration and administration of a tongue cleaner for mechanical cleansing.

\section{REFERENCES}

1. Siregar M L. Oropharyngeal Candidiasis in HIV / AIDS (Kandidiasis Orofaring pada HIV/AIDS). Cakradonya Dent J. 2015; 7(2):807-868. Aceh: Fakultas Kedokteran Universitas Syiah Kuala; $2015 .$.

2. Lukisari C, Setyaningtyas D, Djamhari M. Management of Oral Candisiasis caused by C. Tropicalis (Penatalaksanaan Kandisiasis Oral disebabkan C. Tropicalis). Dentofasial. 2010;9(2). Surabaya: FKG Universitas Airlangga.

3. Gaib Z. Factors that Influence Erythematous Candidiasis in Users with Complete Artificial Teeth (FaktorFaktor yang Berpengaruh terhadapTerjadinya Kandidiasis Eritematosa pada PenggunaGigi Tiruan Lengkap). Manado : Program Studi Kedokteran Gigi Universitas Sam Ratulangi; 2013.

4. Nur'aeny N, Hidayat W, Dewi T S, Herawati E, Wahyuni IS. Profile of Oral Candidiasis in the Mouth Disease Section of Bandung Hospital in the 2010-2014 Period (Profil Oral Candidiasis di Bagian Ilmu Penyakit Mulut RSHS Bandung Periode 2010-2014). Majalah Kedokteran Gigi Indonesia. 2017;3(1). Bandung: Universitas Padjadjaran.

5. Fauzia DA. Relationship of Nutritional Status Based on Anthropometric Index with the Occurrence of Oral Candidiasis in Children Aged 6-12 Years in Five Islamic Boarding Schools in Jember Regency (Hubungan Status Gizi Berdasarkan Indeks AntropometriDengan Terjadinya Oral Candidiasis Pada Ana Usia 6-12 Tahun di Lima Pondok Pesantren di Kabupaten Jember). Jember: Universitas Jember; 2012..

6. Apsari W. Relationship between CD4 + counts and the number of Candida colony sp. in the Oral Cavity of Children Infected with HIV (Hubungan antara Jumlah CD4+ dengan Jumlah Koloni Candida sp. pada Rongga Mulut Anak Terinfeksi HIV). Jakarta: Program Studi Dokter Gigi Spesialis Ilmu Penyakit Mulut; 2014.

7. Ambarawati IGAD. Oral Candidiasis. Case Report. Bali: Universitas Udayana; 2017.

8. Mutiawati VK. Microbiological Examination of Candida Albicans (Pemeriksaan Mikrobiologi pada Candida Albicans). Jurnal Kedokteran Syiah Kuala. 2016;16(1). Banda Aceh: FK Universitas Syiah Kuala.

9. Kusumaputra BH, Zulkarnain I. Management of Mukocutan Candidiasis in Infants (Penatalaksanaan Kandidiasis Mukokutan pada Bayi). Berkala Ilmu Kesehatan Kulit dan Kelamin - Periodical of Dermatology and Venereology. 2014;26(2). Surabaya: FK Universitas Airlangga.

10. Hakim L, Ramadhian MR. Oral candidiasis (Kandidiasis Oral). Majority. 2015;4(8). Bandar Lampung.

11. Martins N, Ferreira IC, Barros L, Silva S, Henriques M. Candidiasis: predisposing factors, prevention, 
diagnosis and alternative treatment. Mycopathologia. 2014;177.

12. Hajjar RR, Kamel HK, Denson K.. Malnutrition in aging. The Internet Journal Geriatrics and Gerontology. 2004;1(1).

13. Puspitawati R, Soedarsono N, Putri EA, Putri AD, Bachtiar BM. Elderly Nutritional Status Effection Salivary Anticandidal Capacity Against Candida Albicans. Dental Journal. 2011;44(2). Jakarta: FKG Universitas Indonesia. 